\title{
犬尿管の平滑筇線維の走行に関する解剖学的検討
}

\author{
秋田大学医学部泌尿器科教室（主任：土田正義教授） \\ 山口哲森田隆近藤俊 土谷順彦
}

\section{ANATOMIC ANALYSIS OF CANINE URETERAL SMOOTH MUSCLE STRUCTURE}

\author{
Tetsu Yamaguchi, Morita Takashi, Kondo Shun and Norihiko Tsuchiya \\ Department of Urology, Akita University School of Medicine
}

(Director: Prof. Seigi Tsuchida)

We have investigated the structure of canine middle ureteral smooth muscle anatomically. In a transverse section inner fibers appeared to be longitudinal and outer fibers appeared to be circular. In the parallel sections with the wall of longitudinal ureteral muscle, inner and outer fibers appeared to be oblique in a mesh structure. In parallel sections with the wall of helical ureteral muscle, fibers appeared to be longitudinal. Anatomical analysis showed that canine ureteral smooth muscle is entirely composed of spinal fibers in a mesh structure and that the helical muscle strip have continuous fibers though the inner fibers have a tendency to run longitudinally and the outer fibers circularly.

Key words: canine ureter, smooth muscle structure

\begin{abstract}
要旨：犬尿管平滑笳の走行を解剖学的に検討した。 犬尿管を輪状に切離した横断面では，内側（粘膜に 近い側）に縦走する筋線維が，外側（外膜に近い側）に輪状に走行する筋線維が観察された。尿管を縦 軸方向に切開した切片では, 内側および外側いずれにおいても絡及合っている斜走筋線維が観察された。 しかし，尿管をら旋状に切開した切片に扔いては連続した筋線維が観察された。これらの事実は，尿管 の筋走行は切開する方向によって異なって観察され，これまで内側では縦走筋，外側では輪状筋が主で あると思われてきた尿管の平滑筋走行が内側も外側も絡み合って斜走して招り，ら旋状に尿管を切開し た場合にのみ連続した筋続維が得られることを示唆している。

キーワード：犬尿管, 平滑筋走行
\end{abstract}

\section{緒言}

多くの解剖学の成書には尿管平滑筋の走行は内層は 縦走筋であり (内縦), 外層は輪状走行 (外輪)を示す と書かれている，尿管平滑筋の構造に関するこれまで の研究報告をみると, $\mathrm{Kench}^{1}{ }^{1}$ は内繸外輪の二層構造, Singh $ら^{2)}$ は内側は緃走で外側は輪状ないし mesh 状 の二層構造, Satani ${ }^{3}$ や Velardo ${ }^{4}$ は内緃, 中輪, 外緃 の三層構造であると述べ, Tanagho5)や $\mathrm{Hanna}^{6}$ や Woodburne $^{7)}$ は尿管の平滑筋線維はあらゆる方向に走 行し層構造を示さないと述べている。 また, Gosling ${ }^{8)}$ は金藤ら ${ }^{91}$ は尿管平滑筋線維はら旋状に走行し mesh 状構造をとり，層構造を示さないと報告している。私 達は, 尿管の平滑筋線維の走行に関して, 未だ明確な 結論の得られない理由の一つが，これまでの解剖学的 研究が尿管を種々の方向から切開して検討していない
点にあると考えた。そこで私達は犬尿管を横断面の方 向，䊓断面の方向，ら旋状方向に切開した標本を作製 して尿管の平滑筋線維の走行を解剖学的に検討し，2， 3 の知見を得たので報告する。

\section{実験方法}

犬尿管切片の採取：体重約 $10 \mathrm{~kg}$ の雄および倠雑種 成犬 4 頭にミオブロック $0.2 \mathrm{mg} / \mathrm{kg}$ を静注して非動化 し，開腹し尿管を長さによって上部，中部，下部に三 分割し中部尿管を摘出した。尿管周囲に付着する脂肪 を丁寧に剥離し, $37^{\circ} \mathrm{C}, 95 \% \mathrm{O}_{2}+5 \% \mathrm{CO}_{2}$ の混合ガスで 酸素化した Krebs 液 $(\mathrm{NaCl} 12.55 \mathrm{mM}, \mathrm{KCl} 5.90 \mathrm{mM}$, $\mathrm{CaCl} 2.36 \mathrm{mM}, \mathrm{MgCl}_{2} 1.18 \mathrm{mM}, \mathrm{NaHCO}_{3} 15.34 \mathrm{mM}$, glucose $11.80 \mathrm{mM} ; \mathrm{pH} 7.4)$ に保存した. Krebs 液の 中で，摘出した尿管から切開方向の種類によって A, $\mathrm{B}, \mathrm{C}$ の三種類の切片を作製した. 即ち, A は幅約 $2 \mathrm{~mm}$ 
図 1 屎管切片の採取方法, 輪状切片 (A) : 尿管走行 に対して横断する方向に切開した切片. 縦軸切片 (B)：尿管走行に対してて縦に切開し板状にした切 片. ら旋状切片 (C) : 尿管走行に対してら旋状に切 開し板状にした切片を示す。

\section{輪状切片}

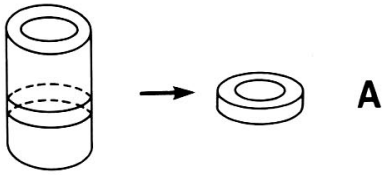

\section{縦軸切片}

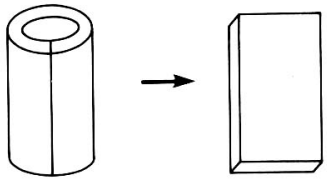

B

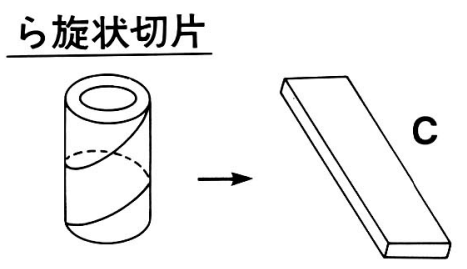

の輪状切片， B は長さ $1 \mathrm{~cm}$ の縦軸切片，C は尿管に 3 Fr 尿管カテーテルを挿入し，尿管を回転させながら約 25 度の角度で切開した長さ約 $1 \mathrm{~cm}$ 幅 $2 \mathrm{~mm}$ のら旋状切 片である。このように切開すると B の縱軸切片の幅は 約 $5 \mathrm{~mm}, \mathrm{C}$ のら旋状切片の幅は, 約 $2 \mathrm{~mm}$ になった(図 1 ).

標本の作製：Susa 液(塩化第二水銀 $4.5 \mathrm{~g}+$ 塩化ナト リウ $\Delta 0.5 \mathrm{~g}$ +蒸留水 $80 \mathrm{cc}+$ 三塩化酢酸 $2 \mathrm{~g}$ +水酢酸 4 $\mathrm{cc}+$ ホルマリン $20 \mathrm{cc}$ ）と $20 \%$ ホルマリンの 2 種類の固 定液を用いて A，B，拈よびC 切片を固定し，99\%× チルアルコールを用いて脱水した．固定脱水後， celloidin-paraffin 重包埋を行い, A 切片は尿管を横断 する方向に，B 打よび C 切片は平滑筋成分を観察する 目的で板状にした尿管平滑筋平面に並行な方向に全層 にわたり microtome 使用して厚さ8 10 $\mu \mathrm{m}$ の連続 切片を作製し、アザン染色を行い観察した。

\section{実験成績}

尿管切片 $\mathrm{A}$ ，即ち中部尿管を横断面で輪状に切開し た切片より作製した標本に扮いては，内側から外側に
図 2 尿管の横断面組織像(倍率 $\times 10)$. 犬尿管を横断 面で観察すると，内側の縦走平滑筋と言われてきた 筋線維よりも外側の輪状平滑筋と言われてきた筋線 維の方がより多く含まれていることが判る.

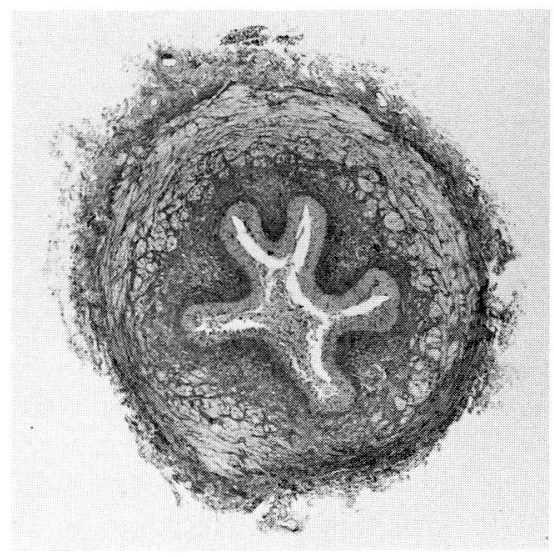

向かって約 4 層〜 6 層の移行粘膜上皮, 線維性組織に 富んだ粘膜固有層, 平滑筋層, 血管やリンパ管を含む 外膜が観察された。平滑筋層においては，これまでに 成書に書かれていた様に，内層には縦方向が外層には 輪状に走行する筋線維が観察された。 またそれら二層 (内縦, 外輪)の筋群の分布量を多ると内縦より外輪平 滑筇と言われているものの方が，より多く占められて いた(図 2 )。しかし，尿管切片 B, 即ち縦軸方向に切 開した尿管切片より平滑筋の層で作製した標本では, 内層の平滑筋線維も外層の平滑笳線維も, 尿管の縦軸 方向に対してほぼ左右対称に絡み合っている斜走線維 であり, 内層の平滑筋線維の走行は外層の平滑筋線維 の走行に比較して尿管の縦軸方向に近くなっていた （図 3，4）. 尿管切片 C 即ちら旋状に切開した尿管切 片より平滑筋の層で作製した標本に扣いては, 斜走し ていた平滑筋線維（図 3，4）は尿管をら旋状に切開 したことにより，連続した尿管平滑筋線維として観察 された(図 5 ), 即ち, 犬尿管をら旋状に切開すれば連 続ふる多くの平滑筋線維を持つ筋切片が得られること が判明した４頭全ての犬尿管においてほとんど同様 の所見であった。

\section{考察}

尿管平滑筋の筋層構築については種々の報告があ る. Kench ${ }^{11}$ は，ヒト尿管を横断面と縦断面で観察し， 内側は䅠走ないしら旋状走行, 外側は輪状走行の二層 構造であると報告し, Singh ら ${ }^{2)}$ は横断面と縦断面で観 察し, 内側は縦走, 外側は輪状ないし mesh 状を呈する 
図 3 B の尿管切片を外側の平滑筋の層で切った標本 像(倍率 $\times 25$ )。これまで外輪と言われてきた平滑筋 は，尿管の哷軸方向に対してほぼ左右対称に絡み 合った斜走線維であることが判る。

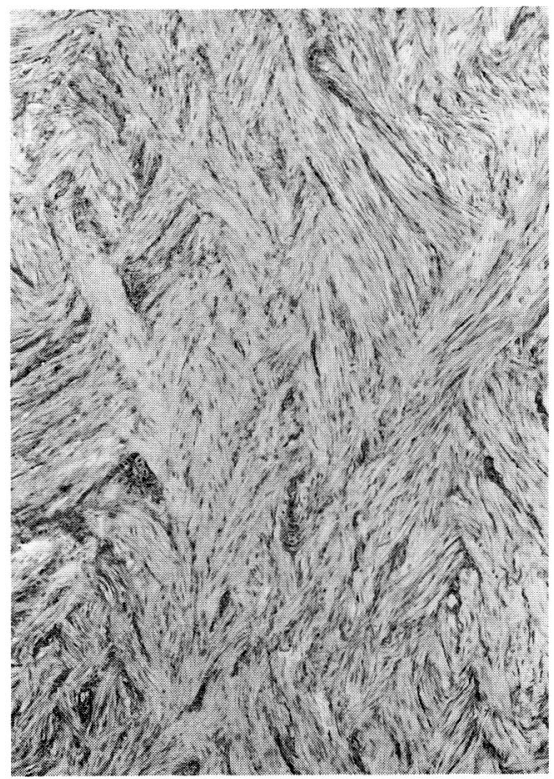

図 4 B の尿管切片を内側の平滑筋の層で切った標本 像(倍率 $\times 25)$ ）－一部尿管粘膜がみえる。これまで内 輪と言われてきた平滑笳は絡み合った斜走線維であ ることが判る。

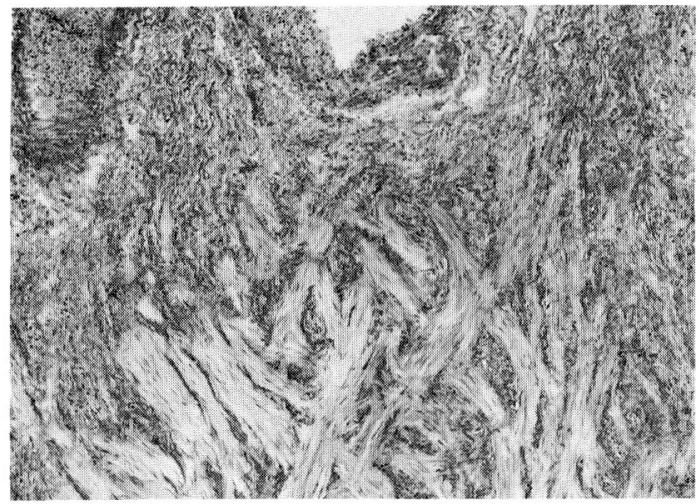

二重構造であると報告している。一方 Satani ${ }^{3)}$ Velardo ${ }^{4}$ はヒト尿管を横断面で観察し, 内縦層, よく 発達した中輪層，およびわずかな外縦層の三層構造で あると報告している。また Tanagho 卜尿管を横断面と縦断面で観察し，尿管の筋線維はあ らゆる方向にら旋状に走り, 層構造を示さないものの,
図 $5 \mathrm{C}$ の尿管切片を平滑筋の層で切った標本像（倍 率 $\times 25)$ ，連続した平滑筋線維が観察される。

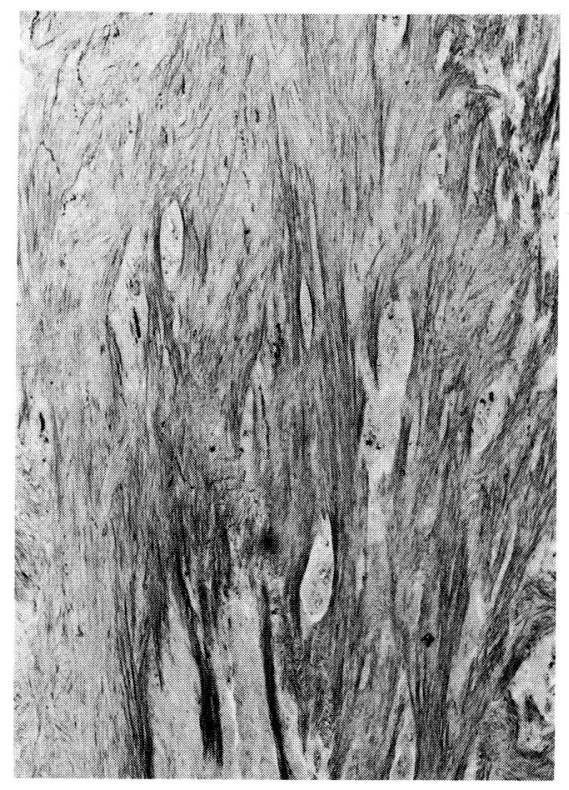

どちらかといえば内側では縦走傾向, 外側では輪状傾 向を示すと述べている．Woodburne ${ }^{7)}$ はヒト尿管を横 断面と綎断面で観察し，尿管の平滑筋線維はあらゆる 方向に走行するため縦走線維あるいは輪状線維として 区別することが難しく，従って層構造も形成しないと 報告している. Gosling ${ }^{8)}$ や金藤ら ${ }^{9)}$ は, ヒト尿管平滑笳 層の平面で切片を作り観察し，筋線維は螺旋状に mesh 構造を形成して走行し，層構造を作らないと述 ベている，このように尿管の平滑筋の走行に関しては 種々の意見があって混乱している、私達は, この混乱 の大きな理由の一つは，これまでの報告者が，尿管の 平滑筋走行を，尿管の横断面や樅断面であるいはそれ 以外の一つの平面で標本を作製し, 研究していること に起因していると考光た。

私達は犬尿管を種々の方向で切開して平滑筋走行を 検討した. 横断面で切開した尿管切片の標本では少し の内縦平滑筋束と多くの外輪走行を示す平滑笳束が観 察され，これまでの諸家の報告1)2) とあまり異なっては いなかった，ところが，管状の尿管を縦軸方向に切開 し筀層に並行な面で作製した標本では，横断面で内縱 と観察された平滑筋線維は串は, 斜走して mesh 構造 を形成し，横断面で外輪と観察された平滑筋線維もい ろいろな角度で斜走し mesh 構造を形成していること が明らかとなった。平滑筋層の平面で作製した標本に 
抬ける斜走線維の走行角度から考兄て，尿管を約 25 度 の角度で螺旋状に切開した標本を作製して観察したと ころ，平滑筋線維の連続している像が得られた，尿管 をら施状に切開した標本を作製し，実際に連続する筋 線維を観察したといら報告は私達が最初である。私達 の観察した犬尿管に抢ける平滑筋線維の走行の事実 は, Gosling ${ }^{8)}$ や金藤ら ${ }^{9)}$ がヒト尿管平滑筋層の平面標 本の像から推測した尿管平滑筋の筋走行を実際に証明 したものと考えられる。これらのことから，尿管平滑 筋構築は種を問わず，筋線維が斜走して mesh 構造を 形成し，層構造を形成しないことが明らかとなった。

尿は腎盎に初発する蠕動収縮 ${ }^{100}$ とよって腎盂から膀 胼まで輸送され，尿管蠕動は尿輸送の主役を担ってい る11)とが知られている．尿を輸送している時の尿管 が筋収縮に関して, Woodburne と Lapides ${ }^{12)}$ は, 尿管 は外径をほとんど変えることなく，筋層の厚さを調整 して尿管の内径を変点，尿を輸送していると述べてい る。私達が本実験で明らかにした尿管平滑筋線維のら 旋構造は，その筋線維の收縮形態から考劣て Woodburne と Lapides の尿管収縮形態に極めて都合が良 い.一方，尿管蠕動の伝播に関して，私達 ${ }^{10)}$ は, 腎盂か ら一度尿管に伝播した蠕動は消学ることなく尿管膀脱 移行部にまで到達することを既に報告している，今回 明らかにした尿管平滑筋のら旋構造は尿管蠕動の伝播 形態から考兵ても極めて合理的であると考兄られた。

これまでの尿管の切片を用いた in vitro の生理薬理 実験をみると，平滑筋切片の採取方向はをちまたちで ある ${ }^{13) \sim 15)}$. 今回の実験結果から，尿管をら旋状に切開 し筋切片を採取すれば，平滑筋線維の連続した切片が 得られることが明らかになり，私達の解剖学的知見は in vitro で尿管平滑筋を用いる生理薬理実験において も大きな助けになると考光られた。

\section{結語}

犬尿管の平滑筋の走行を解剖学的に検討し 2,3 の 知見を得た。

1. 尿管平滑筋は横断面どは内縦外輪の筋構築とし て観察されこの熱点では従来の報告と同じであった。

2.ところが尿管を縦軸方向に切開し,筋層に並行な 面で観察すると，横断面で内縦外輪と観察された線維 はいずれも斜走し，meas 構造を形成していることが 判明した。

3. 尿管を螺旋状に切開して標本を作製すると, 連続 した尿管平滑筇線維が観察された。

稿を終えるにあたり, 御指導, 御校閲を賜った秋田大学第
1 解剖学教室中尾泰右教授ならびに直接の御指導を賜った 同教室斉藤光雄先生に深謝申し上げます。

\section{文献}

1) Kench, J.: A morphometric study of the pelviureteric junction and review of the pathogenesis of upper ureteric obstruction. Pathology, 14, 309-312, 1982.

2) Singh, S.P., Mathur, M.M. and Singh, S.: The musculature of the ureter in mammals, A comparative study. Indian J. Med. Sci., 25, 805-808, 1971.

3) Satani, Y.: Histologic study of the ureter. J. Urol., 3, 247-267, 1919.

4) Velardo, J.T.: Histology of the ureter. in the Ureter, Bergman, H., ed., 2nd ed., p. 13, Springer-Verlag, New York, 1981.

5) Tanagho, E.A.: Ureteral embryology, developmental anatomy, and myology. in Urodynamics: Hydrodynamics of the Ureter and Renal Pelvis. Boyarsky, S., Gottschalk, C. W., Tanagho, E.A. and Zimskind, P.D., ed., p. 3, Academic Press, New York and London, 1971.

6) Hanna, M.K., Jeffs, R.D., Sturgess, J.M. and Barkin, M.: Ureteral structure and ultrastructure. Part I. The normal human ureter. J. Urol., 116, 718-724, 1976.

7) Woodburne, R.T.: The ureter, ureterovesical junction and vesical trigone. Anat. Rec., 151, 243-249, 1965.

8) Gosling, J.A.: The musculature of the upper urinary tract. Acta Anat., 75, 408-422, 1970.

9）金藤博行，千葉民彦，高橋 徹，折笠精一：腎孟尿 管移行部における正常尿管壁の筋層構築一筋束べ クトルの三次元モルフォメトリー一. 日泌尿会誌, 79, 1040-1048, 1988.

10）森田 隆：腎孟笳電図々腎孟内圧变動の同時記録 による犬腎㙉 Pacemaker activity とその伝播に 関する研究. 日泌尿会誌，69，304-314，1978.

11) Saeki, H., Morita, T., Weiss, R.M. and Miyagawa, I.: The role of ureteral peristaltic rate and bolus volume on increasing urine flow. Urologia Internationalis, 41, 174-179, 1986.

12) Woodburne, R.T. and Lapides, J.: The ureteral lumen during peristalsis. Am. J. Anat., 133, 255-258, 1972.

13）近藤 俊, 鈴木隆志, 土田正義：摘出ウサギ腎典尿 管平滑筋切片の收縮張力に及ぼす dobutamine, terbutaline の作用。日泌尿会誌，77，501-506， 1986.

14) Angelo-Khattar, M., Thulesius, O., Cherian, T. and Joseph, L.: Motility of the human ureter, 
with special reference to the effect of indomethacin. Scand. J. Urol., 19, 261-265, 1985.

15) King, W.W. and Cox, C.E. : Bacterial inhibition of ureteral smooth muscle contractility. I.
The effect of common urinary pathogens and endotoxin in an in vitro system. J. Urol., 108, 700-705, 1972.

（1991年 7 月 11 日受理） 